\title{
Burst Container or Vessel
}

National Cancer Institute

\section{Source}

National Cancer Institute. Burst Container or Vessel. NCI Thesaurus. Code C62972.

Problem associated with the pressure inside a vessel or container rising to such a degree that the container ruptures. 